\title{
Peripheral antibody concentrations are associated with highly differentiated T cells and inflammatory processes in the human bone marrow
}

Erin Naismith ${ }^{1 \dagger}$, Luca Pangrazzi ${ }^{1{ }^{*}+}$, Marco Grasse ${ }^{1}$, Michael Keller $^{1}$, Carina Miggitsch ${ }^{1}$, Birgit Weinberger ${ }^{1}$, Klemens Trieb ${ }^{2}$ and Beatrix Grubeck-Loebenstein ${ }^{1}$

\begin{abstract}
Background: Antigen-experienced immune cells migrate back to the bone marrow (BM), where they are maintained in BM survival niches for an extended period. The composition of T cell subpopulations in the BM changes with age, leading to an accumulation of highly differentiated T cells and a loss of naïve $T$ cells. While innate immune cells are also affected by age, little is known about interactions between different adaptive immune cell populations maintained in the BM. In this study, the phenotype and function of innate and adaptive immune cells isolated from human BM and peripheral blood (PB) was analysed in detail using flow cytometry, to determine if the accumulation of highly differentiated $T$ and $B$ cells, supported by the BM niches, limits the maintenance of other immune cells, or affects their functions such as providing protective antibody concentrations.

Results: Total T cells increase in the BM with age, as do highly differentiated $C D 8^{+} T$ cells which no longer express the co-stimulatory molecule CD28, while natural killer T (NKT) cells, monocytes, B cells, and naïve CD8 ${ }^{+}$T cells all decrease in the BM with age. A negative correlation of total T cells with B cells was observed in the BM. The percentage of B cells in the BM negatively correlated with highly differentiated $C D 8^{+} \mathrm{CD} 28^{-} \mathrm{T}$ cells, replicative-senescent $\mathrm{CD} 8^{+} \mathrm{CD} 57^{+} \mathrm{T}$ cells, as well as the $\mathrm{CD} 8^{+} \mathrm{CD} 28^{-} \mathrm{CD} 57^{+}$population. Similar correlations were seen between B cells and the frequency of highly differentiated T cells producing pro-inflammatory molecules in the BM. Interestingly, plasma concentrations of diphtheriaspecific antibodies negatively correlated with highly differentiated $\mathrm{CD} 8^{+} \mathrm{CD} 57^{+} \mathrm{T}$ cells as well as with exhausted central memory $\mathrm{CD}^{+}$and $\mathrm{CD} 4^{+} \mathrm{T}$ cells in the BM. A negative impact on diphtheria-specific antibodies was also observed for $\mathrm{CD}^{+} \mathrm{T}$ cells expressing senescence associated genes such as the cell cycle regulator p21 (CDKN1A), KLRG-1, and elevated levels of reactive oxygen species (ROS).

Conclusion: Our data suggest that the accumulation and maintenance of highly differentiated, senescent, and exhausted T cells in the BM, particularly in old age, may interfere with the survival of other cell populations resident in the BM such as monocytes and B cells, leading to reduced peripheral diphtheria antibody concentrations as a result. These findings further highlight the importance of the BM in the long-term maintenance of immunological memory.
\end{abstract}

Keywords: Bone marrow, Aging, Inflammation, Pro-inflammatory, Immunosenescence, Senescence, Exhaustion, Antibodies, B cells

\footnotetext{
* Correspondence: luca.pangrazzi@uibk.ac.at

†Erin Naismith and Luca Pangrazzi contributed equally to this work.

${ }^{1}$ Institute for Biomedical Aging Research, University of Innsbruck, Rennweg

10, A-6020 Innsbruck, Austria

Full list of author information is available at the end of the article
}

(c) The Author(s). 2019 Open Access This article is distributed under the terms of the Creative Commons Attribution 4.0 International License (http://creativecommons.org/licenses/by/4.0/), which permits unrestricted use, distribution, and

reproduction in any medium, provided you give appropriate credit to the original author(s) and the source, provide a link to the Creative Commons license, and indicate if changes were made. The Creative Commons Public Domain Dedication waiver (http://creativecommons.org/publicdomain/zero/1.0/) applies to the data made available in this article, unless otherwise stated. 


\section{Introduction}

Activated $\mathrm{B}$ and $\mathrm{T}$ cells differentiate into memory and effector cells, and can either proceed to the area of infection, circulate through the blood and lymph, or return to the peripheral lymphoid organs [1]. In addition, many immune cells migrate back to the bone marrow (BM), where they can remain in different activation states for an extended period [2]. Different states of differentiation and activation can be characterized by marker proteins that these immune cells secrete or express on their surface [3]. The BM is well known for haematopoiesis and its function as a primary lymphoid organ, however its role in the longterm maintenance of antigen-experienced immune cells is less well understood. The BM is involved in the regulation, function, and survival of plasma cells, as well as memory B and $\mathrm{T}$ cells [4]. While the number of $\mathrm{CD}^{+}$and $\mathrm{CD}^{+} \mathrm{T}$ cells in the BM is maintained during aging, the composition of subpopulations changes, showing an increase in highlydifferentiated effector memory cells and a decrease in naïve cells [5]. CD28 is a co-stimulatory molecule found on the surface of $\mathrm{T}$ cells which provides the secondary signal upon $\mathrm{T}$ cell activation [6]. Cells that lose CD28 are generally antigen-experienced, highly differentiated, pro-inflammatory, and are preferentially maintained in the BM by IL-15 [7-9]. $\mathrm{CD}^{+} \mathrm{CD} 28^{-} \mathrm{T}$ cells are known to increase in the BM with aging, and under some conditions they acquire the expression of CD57, a marker for replicative senescence and terminal differentiation [10].

As the space within the BM is restricted, and different populations share the same survival factors, a question of interest is whether the accumulation of some immune cells may interfere with the maintenance of other subsets. In particular, highly differentiated $\mathrm{T}$ cells in the BM may interfere with the maintenance of other populations such as monocytes and B cells, and alter the BM environment with the production of pro-inflammatory molecules. As IL-15 expression increases with aging [7, 11], and it is known to be important for the survival of $\mathrm{CD}^{+} \mathrm{CD} 28^{-} \mathrm{T}$ cells, we hypothesized that, in old age, BM niches may recruit high frequency of highly differentiated $\mathrm{CD}^{+} \mathrm{T}$ cells, limiting the space for other cell types [7]. The B cell compartment in the BM is also affected by age and plasma cell numbers decrease [12]. Distinct niches provided by cytokine-producing stroma cells have also been described for murine memory $\mathrm{CD}_{4}^{+} \mathrm{T}$ cells [13].

Cellular senescence and exhaustion represents typical hallmarks of aging [14]. Senescent cells secrete soluble and insoluble factors such as interleukins, chemokines, fibronectin, and collagens [15], which modulate signalling pathways associated with inflammation and malignancies, in addition to directly secreting pro-inflammatory cytokines inducing low-grade chronic inflammation, which when present in the BM may affect its ability to harbor long-living immune cells $[7,16]$. Cellular senescence is a process by which the emergence of transformed cells is prevented via permanent cell cycle arrest, during which the cells remain metabolically active [17]. p21 is a central regulator of cell cycle progression and it is a major target of the p53 pathway, which is activated by DNA damage or other stresses [18]. p21 promotes cell cycle inhibition, protect cells from apoptosis, and can thereby be used as a reliable marker for senescence [19]. In addition to p21, killer cell lectin-like receptor subfamily G, member 1 (KLRG-1) represents a marker for $\mathrm{T}$ cell senescence. KLRG-1 expression on $\mathrm{CD}^{+} \mathrm{T}$ cells indicates a subpopulation which is unable to undergo further cell division and is therefore terminally differentiated or replicatively senescent [20]. KLRG-1 is negatively regulated by programmed cell death protein 1 (PD-1) [21]. PD-1 is a characteristic marker for exhaustion [22], and was initially recognized for its ability to induce apoptosis [23], however it should not be regarded as a definitive marker for exhausted cells in general [24]. PD-1 is an inhibitory receptor which is expressed on the surface of activated T cells, and is maintained during chronic infection [25]. PD-1 has two ligands, PDL-1 and PDL-2, which upon binding activate inhibitory signals for cell cycle progression [21] and impair T cell receptor (TCR) signalling [23]. Positive correlations have been observed between PD-1 and the proliferation marker Ki67 on memory $\mathrm{CD}^{+}$and $\mathrm{CD}^{+} \mathrm{T}$ cells, and negative correlations between PD-1 density and Ki67 expression in central memory (CM) $\mathrm{CD}^{+} \mathrm{T}$ cells [24], therefore the presence of PD-1 on nonproliferating cells, such as CM cells, indicate that they are exhausted [23]. The expression of p21, KLRG-1, and PD-1 are all known to increase with age [16].

These antecedents have led to the hypothesis that the accumulation and maintenance of effector, senescent, and/or exhausted $\mathrm{T}$ cells in aged BM may disrupt or alter the immunological function of the BM. We consider the consequential displacement of other cell types, such as $\mathrm{CD}^{+} \mathrm{T}$ cells, B cells, and plasma cells, due to competition for stromal niches. Long-lived plasma cell survival is mediated by stromal cells in the BM [26]. Therefore we hypothesized that changes in the BM environment may lead to impaired antibody production. To assess this, the concentration of Diphtheria-specific antibody was measured in PB. As Diphtheria-specific antibodies are not maintained well with aging [27], we hypothesized that the competition for space, as well as the age-related changes taking place in the BM environment in old age, may directly contribute to decreased immune responses against Diphtheria observed in the elderly.

In the current study, we investigated whether competition for space between $\mathrm{B}$ and $\mathrm{T}$ cell subpopulations takes place in the BM. In addition, we assessed whether the accumulation of highly differentiated $\mathrm{CD}^{+} \mathrm{T}$ cells, which have been described to support inflammation and oxidative stress in the BM [11], may be negatively associated 
with the maintenance of long-lived plasma cells, affecting the production of diphtheria-specific antibody in the periphery as a result.

\section{Materials and methods Sample preparation}

Samples were obtained from systemically healthy individuals who do not suffer from diseases known to affect the immune system. All samples were obtained from people undergoing elective surgeries because of osteoarthrosis. The donors comprised of 95 individuals aged between 39 and 87 (mean age: $67.45 \pm 10.95$, mean BMI: $27.9 \pm 5.03$, sex: $50 \mathrm{~F}, 46 \mathrm{M})$. The number of samples used in individual experiments are given in the figures and legends.

For the isolation of bone marrow mononuclear cells (BMMCs), a fragment of substantia spongiosa osseum, which would otherwise be discarded was collected during routine hip replacement surgery. The bone was further fragmented and treated with purified collagenase (CLSPA, Worthington Biochemical; $20 \mathrm{U} / \mathrm{ml}$ ) in complete RPMI medium (RPMI 1640; Corning supplemented with 10\% FCS, $100 \mathrm{U} / \mathrm{ml}$ penicillin, and $100 \mu \mathrm{g} / \mathrm{ml}$ streptomycin; Sigma) for $1 \mathrm{~h}$ at $37^{\circ} \mathrm{C}$. BMMCs were extracted using a filtered tube centrifugation step, and then purified using density gradient centrifugation (Lymphoprep; ${ }^{\circ}$ Stemcell technologies). Heparinised blood from the same donors was collected, and peripheral blood mononuclear cells (PBMCs) were also purified by density gradient centrifugation.

\section{Flow cytometry}

Immunofluorescence stainings were done using conjugated surface antibodies. BMMCs and PBMCs were incubated with flourochrome-labeled antibodies for $20 \mathrm{~min}$ at $4{ }^{\circ} \mathrm{C}$. Cells were washed with PBS and measured using a FACSCanto II (BD Biosciences). The production of IFN $\gamma$ and p21 was measured by intracellular staining and flow cytometry. BMMCs and PBMCs were stimulated for $4 \mathrm{~h}$ with $30 \mathrm{ng} / \mathrm{ml}$ PMA and $500 \mathrm{ng} / \mathrm{ml}$ ionomycin in the presence of $10 \mathrm{mg} / \mathrm{ml}$ BFA. After the surface staining cells were fixed and permeabilised using the Cytofix/Cytoperm kit (BD Pharmingen), and incubated with intracellular antibodies. Cells were washed and measured using a FACSCanto II (BD Biosciences). Detailed information on the antibodies used can be found in Additional file 1: Table S1. Dead cells were excluded using a fixable viability dye (Zombie Violet ${ }^{\mathrm{mu}}$ Fixable Viability Kit, Biolegend). Flow cytometry data were analysed using FlowJo v10 software.

\section{Antibody concentration measurement}

Diphtheria-specific antibodies were measured in plasma obtained from peripheral blood. Microtiter plates were coated with $1 \mu \mathrm{g} / \mathrm{ml}$ diphtheria toxoid (Statens Serum Institute) and blocked with $0.01 \mathrm{M}$ Glycin. Peroxidase- labelled rabbit anti-human IgG antibody (Chemicon/ Millipore) was used as secondary antibody. Specific IgG antibodies were quantified in $\mathrm{IU} / \mathrm{ml}$ using standard human anti-diphtheria sera (National Institute for Biological Standards and Control). The detection limit was $0.01 \mathrm{IU} / \mathrm{ml}$, and values below this concentration were set to $0.005 \mathrm{IU} / \mathrm{ml}$ for calculation of geometric mean concentrations (GMC). Ab concentrations above $0.1 \mathrm{IU} / \mathrm{ml}$ were considered protective [28].

\section{Isolation of RNA and quantitative RT-PCR}

RNA was isolated from purified BMMCs using the RNeasy Plus mini kit (Qiagen). First-strand cDNA synthesis was done using a reverse transcription system (Promega). Quantitative RT-PCR experiments were done using the LightCycler 480 System (Roche Diagnostics), $2 \times$ SYBR Green 1 Master (Roche Diagnostics), and $\beta$-actin as housekeeping gene for relative quantification of effector/memory cell survival factors. Sequence-specific oligonucleotide primers were designed using Primer3 software [26] and synthesized by MWG Biotech (Ebersberg, Germany). The following primers were used: IFN $\gamma F W$ 5'- GTAGCAATTGCCTG AATAATG-3', IFNyRW 5' - GTTGTGCCTTCTGA AACT-3', IL-15FW 5'-ATTTTGGGCTGTTTCAGTGC3', IL-15RW 5'-TTACTTTGCAACTGGGGTGA-3'; $\beta A C-$ TINFW 5'-TCCTCCCTGGGCATGGAGT-3', TINRW 5'-TCTCCTTCTGCATCCTGTCG-3'.

\section{Measurement of ROS}

BMMCs and PBMCs were incubated with the fluorescent dye dihydroethidium (Sigma-Aldrich) at a concentration of 1:250 in complete RPMI for $20 \mathrm{~min}$ at $37^{\circ} \mathrm{C}$. Cells were washed in PBS, measured with a FACSCanto II (BD Biosciences).

\section{Statistical analysis}

Pearson correlations were used to determine the statistical significance as indicated in the figure legends. $p$ values less than 0.05 were considered significant. To exclude the influence of age on the correlations, partial correlations controlling for the variable age were performed using SPSS. With this method, the effect of age on the correlations has been removed completely. The correlation values calculated without controlling for age are shown in Additional file 1: Table S1. For the comparisons between populations (Figs. 1, 2 and Additional file 1: Table S1), $\mathrm{p}$ values were adjusted for multiple comparisons using Bonferroni corrections.

\section{Study approval}

Study approval was given by the local institution, and written informed consent was received from all participants prior to their inclusion in the study in accordance with the Declaration of Helsinki. 


\section{Results}

Competition between T cells and B cells in the BM

Major lymphocyte populations and sub-populations based on differentiation were analysed in BMMCs and PBMCs of 95 donors with an age range of 39 to 87 years. As the frequency of many populations, such as $\mathrm{T}$ cells, NKT cells, monocytes and B cells, increase in the BM with age (Table 1), all further calculations were statistically corrected for age. Correlation coefficients $\left(r_{p}\right)$ obtained considering the influence of age are reported in Additional file 1: Table S2. Gating strategy used to define these populations is shown in Additional file 2: Figure S1. Representative flow plots in young ( 31 years) and old (89 years) donors are shown in Additional file 2: Figure S2. Within the BM environment, strong negative correlations could be seen between $\mathrm{T}$ cells and B cells $(p<0.001)$ (Fig. 1a), and T cells and monocytes $(p=0.0095)$ (Fig. 1b). No correlation was found between $\mathrm{T}$ cells and NKT cells (Fig. 1c), or T cells and NK cells (Fig. 1d). These data suggest that populations in the BM may influence one another and that there may be a certain level of competition between $\mathrm{T}$ cells and B cells, as well as monocytes.
Highly differentiated $C D 8^{+}$T cells negatively influence B cells in the BM

The surface markers CD28 and CD57 were used to define populations of highly differentiated $\mathrm{CD}^{+} \mathrm{T}$ cells (Additional file 2: Figure S1). To determine if the accumulation of these highly differentiated $\mathrm{CD}^{+} \mathrm{T}$ cell subsets may negatively affect the maintenance of other cell populations we correlated the frequency of $\mathrm{CD}_{2} 8^{-}$, $\mathrm{CD} 57^{+}$, and $\mathrm{CD} 28^{-} \mathrm{CD} 57^{+} \mathrm{CD} 8^{+} \mathrm{T}$ cells with $\mathrm{B}$ cell frequency in the BM.

Interestingly, $\mathrm{B}$ cells correlated negatively with the levels of $\mathrm{CD}^{+} \mathrm{CD}^{-} 8^{-}(p=0.0194)$ (Fig. 2a), CD8 ${ }^{+} \mathrm{CD} 57^{+}$ $(p=0.0788)$ (Fig. 2b), and $\mathrm{CD}^{+} \mathrm{CD} 28^{-} \mathrm{CD}^{+} 7^{+} \quad(p=$ $0.0288) \mathrm{T}$ cells (Fig. 2c). These data suggest that $\mathrm{B}$ cells in the BM may be influenced by highly differentiated/ terminally differentiated $\mathrm{CD}^{+} \mathrm{T}$ cells.

\section{Pro-inflammatory molecules are negatively associated} with B cell frequency in the BM

An elevated baseline level of pro-inflammatory markers, known as "inflammaging", occurs during aging, therefore we quantified the expression of IFN $\gamma$ and IL-15 in BMMCs at the mRNA level. IL-15 is produced by some $\mathrm{BM}$ cells and postulated to support highly differentiated,
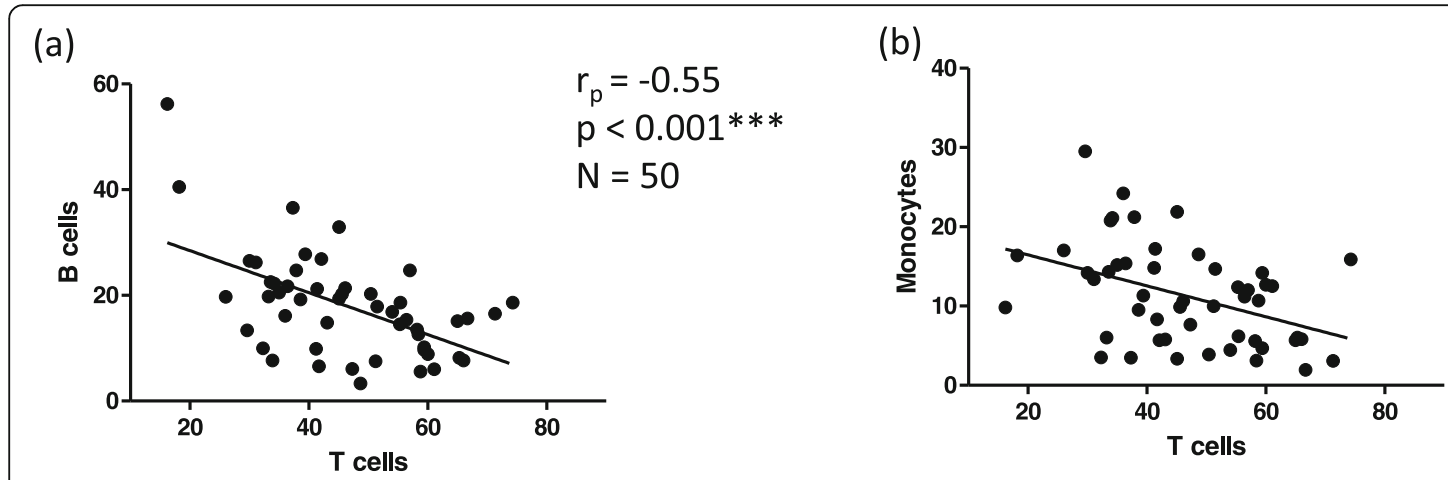

(c)

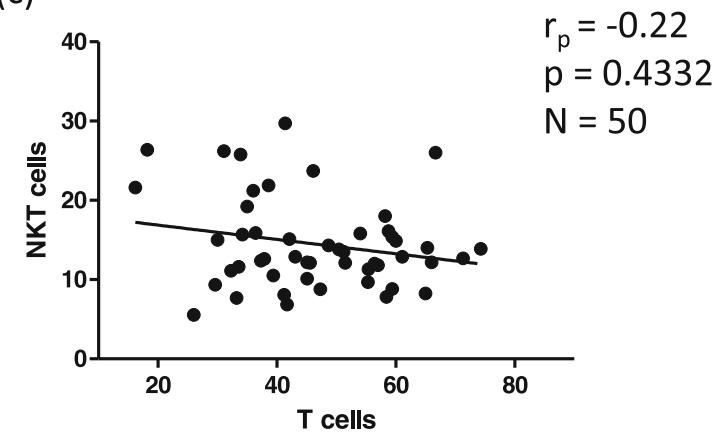

(d)

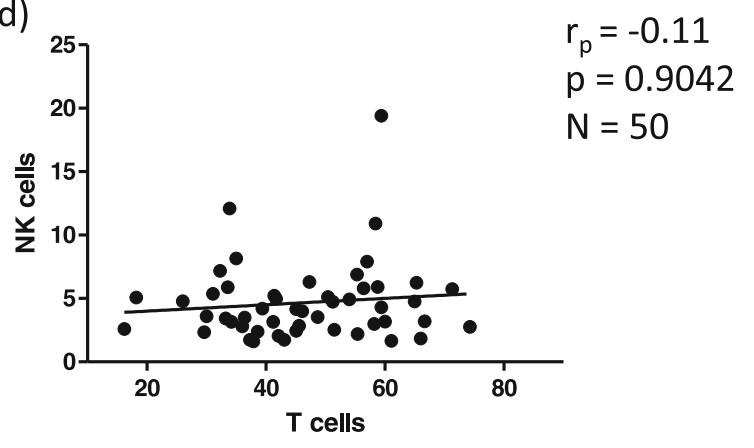

Fig. 1 Correlations of T cells with B cells (a), Monocytes (b), NKT cells $(\mathbf{c})$, and NK cells $(\mathbf{d})$ in the human BM. T cells are defined as CD3 ${ }^{+}$ lymphocytes $\left(\mathrm{CD}_{4} 5^{+}\right), \mathrm{B}$ cells as CD19 ${ }^{+}$lymphocytes. Monocytes are defined as $\mathrm{CD} 3^{-} \mathrm{CD} 14^{+}$lymphocytes, NKT cells as $\mathrm{CD} 3^{+} \mathrm{CD} 56^{+}$lymphocytes, and NK cells as $\mathrm{CD}^{-} \mathrm{CD}_{56}{ }^{+} \mathrm{CD} 14^{-}$lymphocytes. Correlation coefficients $\left(r_{p}\right)$ and significances were calculated according to Pearson with correction for age, values below 0.05 were considered significant; $p<0.05$ is indicated by $*, p<0.01$ is indicated by **, $p<0.001$ is indicated by ***. N: number of samples 

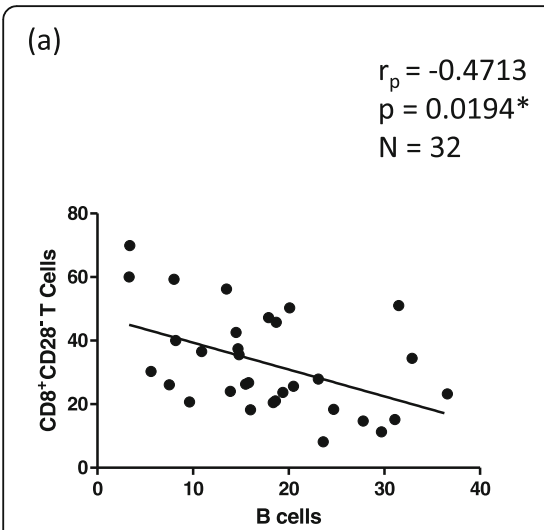

(b)

$$
\begin{aligned}
& r_{p}=-0.3616 \\
& p=0.0788 \\
& N=32
\end{aligned}
$$

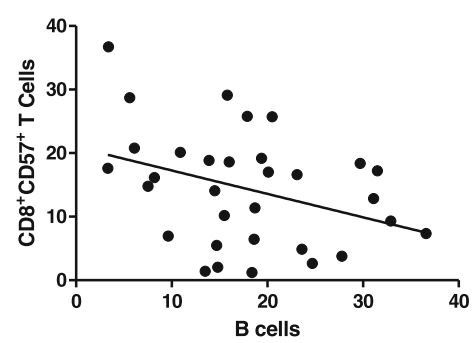

(c)

$r_{p}=-0.4438$
$p=0.0288^{*}$
$N=32$

Fig. 2 Correlations of B cells with highly-differentiated CD8 $8^{+} C D 28^{-}$T cells (a), immunosenescent/replicative senescent $C D 8^{+} C D 57^{+}(\mathbf{b})$, and highly-differentiated, replicative senescent $\mathrm{CD} 8^{+} \mathrm{CD} 28^{-} \mathrm{CD} 57^{+} \mathrm{T}$ cells in the human BM. B cells are defined as CD19+ lymphocytes, T cells are defined as $\mathrm{CD}^{+}$lymphocytes. Correlation coefficients $\left(r_{p}\right)$ and significances were calculated according to Pearson with correction for age

Table 1 Correlations of cell populations in the human BM and PB with age

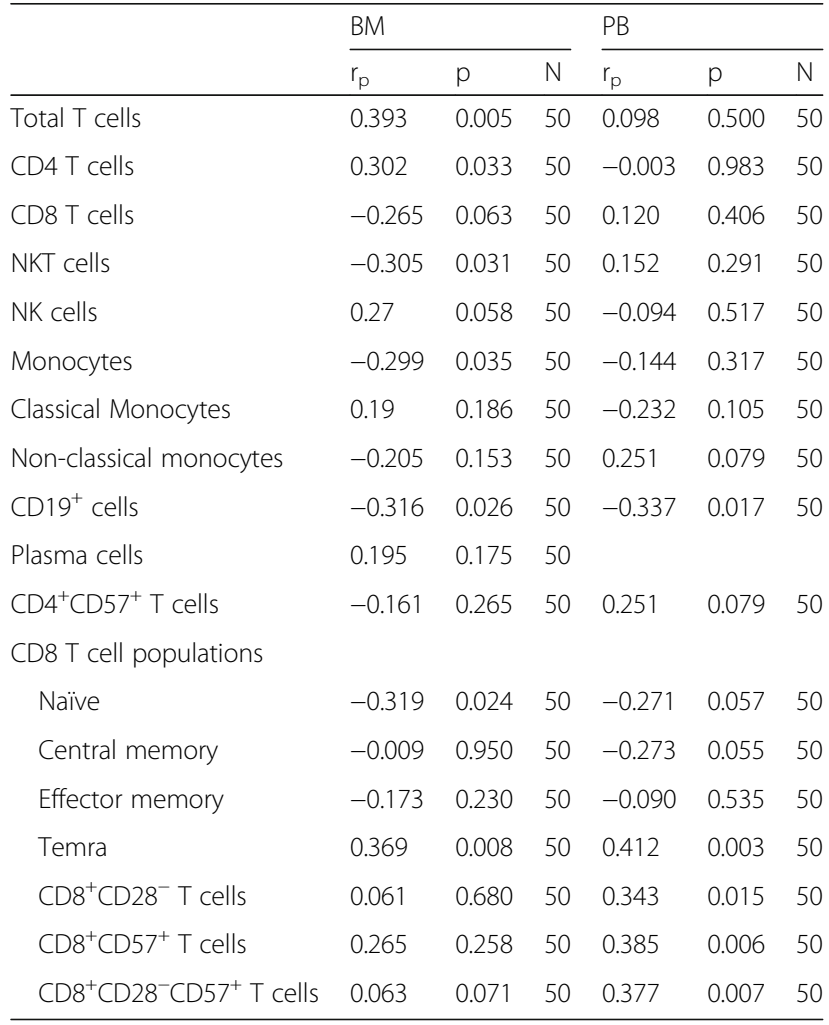

Correlation coefficients $\left(r_{p}\right)$ and significances were calculated according to Pearson with correction for age, values below 0.05 were considered significant. $\mathrm{N}$ : number of samples. T cells are defined as $\mathrm{CD}^{+}$Lymphocytes $\left(\mathrm{CD} 45^{+}\right)$, NKT cells as $\mathrm{CD}^{+} \mathrm{CD}^{+} 6^{+}$Lymphocytes, NK cells as $\mathrm{CD}^{-} \mathrm{CD} 56^{+} \mathrm{CD} 14^{-}$Lymphocytes, Monocytes are defined as $\mathrm{CD}^{-} \mathrm{CD}_{14}{ }^{+}$lymphocytes, and $\mathrm{B}$ cells as $\mathrm{CD} 19^{+}$Lymphocytes and therefore more pro-inflammatory $\mathrm{T}$ cells [7] .The expression levels of IFNY negatively correlated with $\mathrm{B}$ cells in the BM ( $p=0.03)$ (Fig. 3a), while a negative trend could be seen between IL-15 expression levels and B cells in the BM $(p=0.10)$ (Fig. 3b). In addition, the frequency of $\mathrm{T}$ cells producing IFN $\gamma$ after stimulation negatively correlated with the percentage of $\mathrm{B}$ cells in the BM $(p=0.02) \quad($ Fig. 3c). From these data we conclude that, in addition to highly differentiated $\mathrm{T}$ cells, a pro-inflammatory environment may also have a negative impact on B cell maintenance in the BM.

\section{Concentrations of diphtheria-specific antibodies in the plasma correlate with cell populations, cellular senescence and ROS in the BM}

The support of long-lived plasma cell survival in the BM is thought to be mediated by cells in the BM niches [26]. Thus we hypothesized that changes in the BM environment affect antibody concentrations in the periphery. Diphtheria-specific antibody concentrations were measured in the plasma and correlated with cell populations from the $\mathrm{BM}$ and $\mathrm{PB}$ to indicate possible links between antibody concentrations in the blood and the BM environment. We investigated markers of differentiation, such as CD57, markers of exhaustion, such as PD-1, markers of cellular senescence, including p21 and KLRG-1, and the presence of ROS as an indicator for oxidative stress. Gating strategy used to define these populations is reported in Additional file 2: Figures S3-S4. Negative correlations were observed between diphtheria-specific antibody concentrations and highly differentiated $\mathrm{CD} 8{ }^{+} \mathrm{CD} 57^{+} \mathrm{T}$ cells in the BM $(p=0.044)$, whereas no correlation could be seen with cells in the PB (Fig. 4a). PD- $1^{+} \mathrm{CM} \mathrm{CD} 8^{+} \mathrm{T}$ cells and PD- $1^{+} \mathrm{CM} \mathrm{CD} 4^{+} \mathrm{T}$ cells in the BM $(p=0.029 \& 0.039$ respectively) (Fig. $4 \mathrm{~b}$ and $\mathrm{c}-$ upper panels), negatively correlated with peripheral antibody concentrations. PD- $1^{+}$ $\mathrm{CM} \mathrm{CD} 8^{+} \mathrm{T}$ cells derived from peripheral blood showed a 


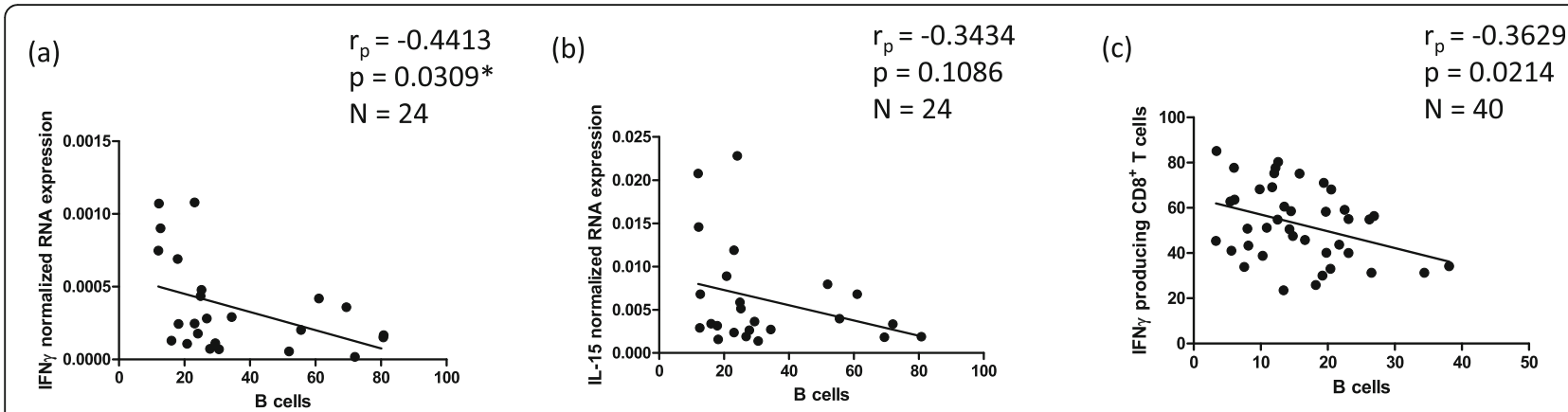

Fig. 3 Correlations of B cells with the normalized RNA expression of both IFNY (a) and IL-15 (b), and IFNy producing CD8 ${ }^{+}$T cells (c) in the human BM. B cells are defined as CD19+ lymphocytes, T cells are defined as CD3 $3^{+}$lymphocytes. Cells were stimulated with PMA and lonomycin for $4 \mathrm{~h}$ at $37^{\circ} \mathrm{C}$. Correlation coefficients $\left(r_{p}\right)$ and significances were calculated according to Pearson with correction for age

similar trend, but this correlation was not statistically significant (Fig. 4b and c - lower panels). These data support the hypothesis that the accumulation of senescent and/or exhausted $\mathrm{T}$ cells in the BM, negatively affect peripheral antibody concentrations.

The cellular senescence marker p21 was measured in total BMMCs as well as in different $\mathrm{T}$ cell subpopulations (Fig. 5). Diphtheria-specific antibody concentrations negatively correlated with the mean fluorescence intensity (MFI) of p21 in all BMMCs $(p=0.0487)$, as well as with the percentage of $\mathrm{CD} 8^{+} \mathrm{CD} 57^{+}$and $\mathrm{CD} 8{ }^{+} \mathrm{KLRG}^{-} 1^{+} \mathrm{BM}$ T cells expressing p21 $(p=0.0043 \& 0.0013$ respectively) (Fig. 5a-c, upper panels). In contrast, in the $\mathrm{PB}$, this correlation was only observed for $\mathrm{CD} 8^{+} \mathrm{CD} 57^{+} \mathrm{T}$ cells $(p=$ 0.0497), when the same populations were analysed (Fig. 5a-c, lower panels). The levels of ROS were additionally measured, and a strong negative correlation could be seen between diphtheria-specific antibody concentrations and ROS levels in BMMCs ( $p=$ 0.0132) (Fig. 5d, upper panel), but not with ROS levels in PBMCs (Fig. 5d, lower panel). These data further corroborate our findings that senescent cells and/or highly-differentiated cells, as well as elevated ROS levels in the BM can negatively impact peripheral antibody concentrations.

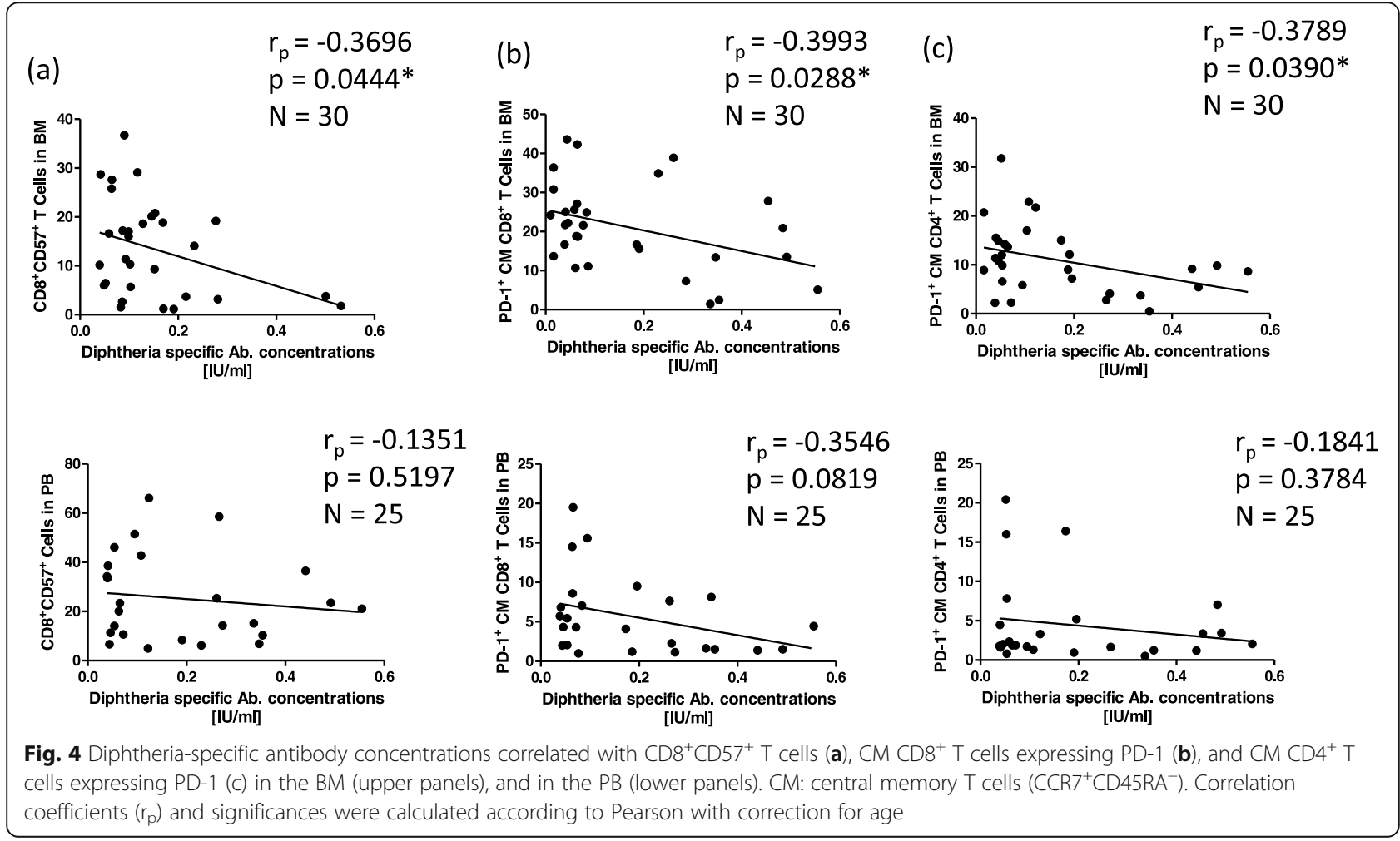



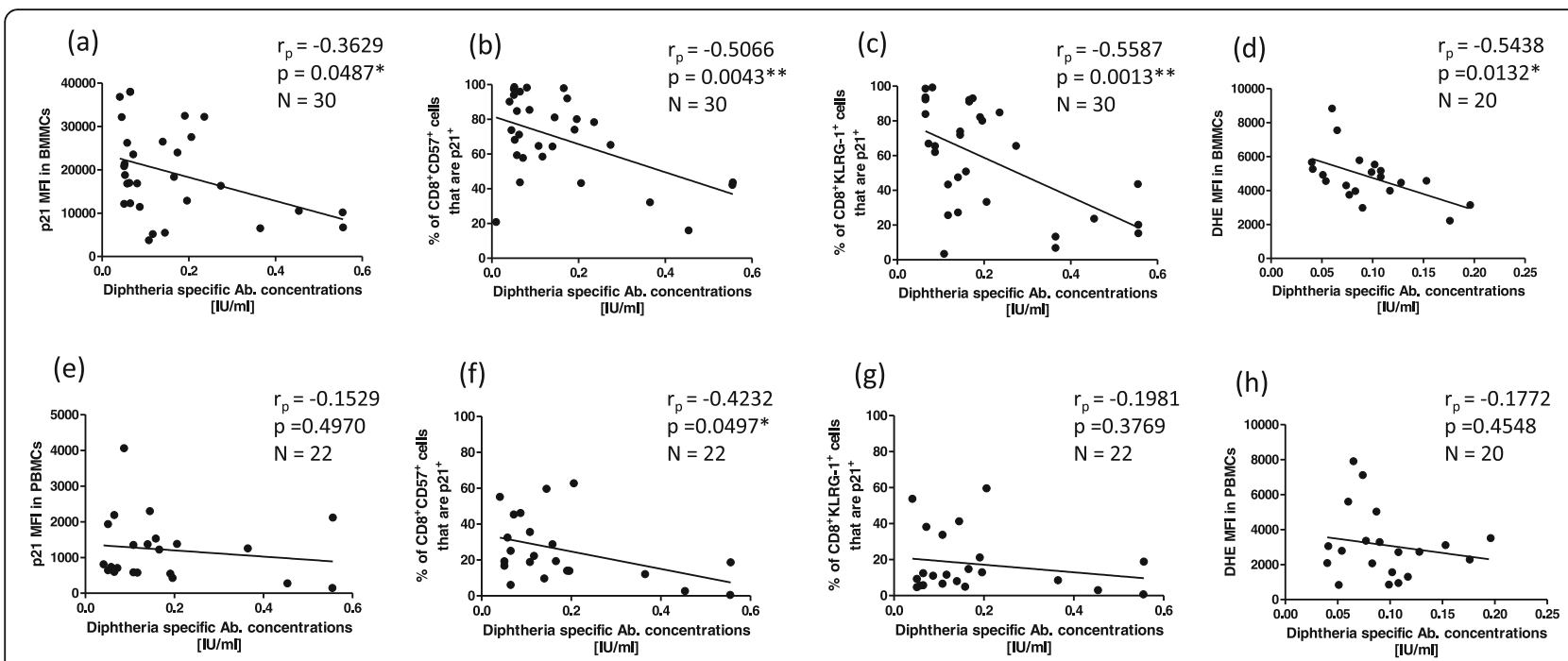

Fig. 5 Diphtheria-specific antibody concentrations were correlated with; the mean fluorescence intensity of p21 (a), CD $8^{+} \mathrm{CD} 57^{+} \mathrm{T}$ cells expressing p21 (b), CD8 ${ }^{+}$T cells expressing KLRG-1 and p21 (c), and Reactive oxygen species (d): in the BM or all BMMCs (upper panels) and in the PB or all PBMCs (lower panels). Cells were stimulated with PMA and lonomycin for $4 \mathrm{~h}$ at $37^{\circ} \mathrm{C}$. Correlation coefficients $\left(r_{p}\right)$ and significances were calculated according to Pearson with correction for age

\section{Discussion}

The composition of immune cells in the BM changes with aging, and a shift from a naïve, to highly differentiated populations can be observed [29]. This shift is often used to describe immunosenescence [29]. As chronic infection, or repeated $\mathrm{T}$ cell activation can also drive these changes within the $\mathrm{T}$ cell compartment, Cytomegalovirus (CMV), is often referred to as a contributor to immunosenescence in the PB [30] and the BM [11]. CMV, a lifelong-persisting virus from the herpes virus family present in $60-100 \%$ of the elderly population (depending on the cohort), causes irreversible changes within the $\mathrm{CD}^{+} \mathrm{T}$ cell compartment, and the $\mathrm{T}$ cell repertoire of a young $\mathrm{CMV}$-seropositive individual is often somewhat similar to an old CMV-seronegative repertoire. [11, 31]. The changes which we observed were even more pronounced in CMV positive individuals (data not shown).

The BM is important for the maintenance of antigenexperienced adaptive immune cells, in particular longlived immune cells which populate survival niches in the $\mathrm{BM}$ [32]. After antigenic stimulation, effector/memory $\mathrm{T}$ cells and long-lived plasma cells accumulate within BM survival niches where they can be maintained for an undefined amount of time [33]. Our lab has previously shown that highly differentiated $\mathrm{CD}^{+} \mathrm{T}$ cells accumulate in the BM $[7,9]$. The phenotype of these effector cells may be affected by the BM environment, or the different cell populations simultaneously present in the BM may interact and compete for space and/or the possibly limited survival factors available in the BM.

Among the immunological changes of the BM seen during aging, the percentage of $\mathrm{T}$ cells increases, in contrast to the $\mathrm{PB}$ where both the number and functionality decrease [34]. We questioned if the increase in $\mathrm{T}$ cell numbers in the BM could be due to the accumulation of senescent or exhausted cells $\mathrm{T}$ cells, thus affecting other cell populations, in particular B cells, in the $\mathrm{BM}$. The negative correlations between both $\mathrm{T}$ cells and $\mathrm{B}$ cells, and $\mathrm{T}$ cells and monocytes independent of age, incite the idea that these events could be related.

IL-7 is a key survival factor for memory $\mathrm{CD} 4^{+}$and $\mathrm{CD}^{+} \mathrm{T}$ cells, acting as a central regulator for their survival and homeostasis [35]. In addition to this, IL-7 represents an important B cell factor, supporting B cell development, and regulating the proliferation and survival of B cell progenitors [36]. Other studies have shown that IL-7 supports B cells indirectly by inducing CD70 and BAFF expression in resting memory $\mathrm{T}$ cells, which in turn stimulate memory $\mathrm{B}$ cell activation and antibody production [37]. This cytokine has also been shown to play an important role in regulation of monocytes/macrophages [38]. Thus, as different immune cell populations share the same survival factor IL-7, which is produced by stromal cells located in restricted areas within the marrow [14], we can hypothesized that IL-7 may play an important role in the competition for space, at least between $\mathrm{T}$ cells, B cells and monocytes. Indeed, negative correlations between $B$ and $\mathrm{T}$ cells, and monocytes and $\mathrm{T}$ cells in the BM have been observed in our study.

With age, more and more $\mathrm{T}$ cells lose the surface costimulatory molecule CD28, which is important for $\mathrm{T}$ cell activation [39]. Several causes are attributed to the loss of CD28 on the surface of $\mathrm{T}$ cells including chronic antigen stimulation and repeated $\mathrm{T}$ cell activation [10]. 
In addition to the loss of CD28, some cells gain expression of CD57, which is associated with an inability to proliferate, as well as high cytotoxic potential [40]. Therefore these $\mathrm{CD} 8^{+} \mathrm{CD} 28^{-} \mathrm{CD} 57^{+} \mathrm{T}$ cells are considered terminally differentiated $\mathrm{T}$ cells $[10]$. The strong negative correlations between $\mathrm{B}$ cells and $\mathrm{CD} 8^{+} \mathrm{CD} 57^{+}, \mathrm{CD}^{+} \mathrm{CD} 28^{-}$, and $\mathrm{CD} 8^{+} \mathrm{CD} 28^{-} \mathrm{CD} 57^{+} \mathrm{T}$ cells, suggest that these highly differentiated $\mathrm{T}$ cells affect $\mathrm{B}$ cell maintenance in the BM. In contrast to $\mathrm{T}$ cells of earlier differentiation stages, highly differentiated $\mathrm{T}$ cells are less responsive to IL-7, as they express lower levels of IL-7R $\alpha$ [41]. It therefore seems unlikely that they compete with B cells for this cytokine [41], but rather that the correlations are a result of an indirect effect. The accumulation of highly differentiated $\mathrm{T}$ cells, leading to increased levels of proinflammatory cytokines and ROS [11] might additionally result in a stressful environment for B cells [42].

With age, a quantitative and qualitative decline of $\mathrm{B}$ cell responses can be observed. It has previously been pointed out, that functional alterations in aged $\mathrm{T}$ cells contribute to the defects in B cell function [43]. CD19 ${ }^{+}$ $\mathrm{B}$ cells are known to decrease in the BM with age [43], and the expression of the adhesion molecules CD49d and CD50, which are important for B cell adhesion to epithelium, are reduced in elderly subjects [44]. IFNY in particular, produced in higher amounts by terminally differentiated $\mathrm{T}$ cells, has been described to inhibit $\mathrm{B}$ cell differentiation [45]. The quantitative and qualitative decline of B cell responses, and disadvantageous intrinsic changes in B cells have also previously been explored, specifically independent of $\mathrm{T}$ cell influence, as defective aged $\mathrm{T}$ cells are suspected to contribute to $\mathrm{B}$ cell decline [43]. We first considered the mRNA expression of IFN $\gamma$ and IL-15 in all BMMCs, and we saw a significant negative correlation between IFNy and B cells in the BM. In addition to the mRNA expression we also considered protein expression of IFN $\gamma$ by individual cells and found strong negative correlations between $\mathrm{B}$ cells and pro-inflammatory IFN $\gamma$ producing $\mathrm{CD}^{+}$ $\mathrm{T}$ cells. We also found strong negative correlations between $\mathrm{B}$ cells and pro-inflammatory IFN $\gamma$ producing $\mathrm{CD}^{+} \mathrm{CD} 57^{+}$, $\mathrm{CD} 8^{+} \mathrm{CD} 28^{-}$, and $\mathrm{CD}^{+} \mathrm{CD} 28^{-} \mathrm{CD} 57^{+} \mathrm{T}$ cells (data not shown), highlighting the negative influence that a pro-inflammatory environment can have on B cells. Highly differentiated $\mathrm{T}$ cells which accumulate in the BM are more pro-inflammatory [11], and a pro-inflammatory environment can negatively impact B cell development [45]. After B cells are activated, they rapidly proliferate and undergo somatic hyper mutation, changing the affinity of their Ig variable regions [46]. These "class-switched" B cells are experienced immune cells and have been reported to be higher in the peripheral blood of smokers [47]. All of this considered, suggests that the loss of B cell diversity is strongly associated with poor health rather than age [48], and that inflammation clearly has a large effect on BM cell populations. The presence of IFNY in the bone due to antigen-driven $\mathrm{T}$ cell activation has previously been shown to stimulate osteoclast formation, resulting in bone loss [49], further highlighting the dramatic effects that inflammation can have on the bone/BM. These data support out hypothesis that highly differentiated $\mathrm{CD} 8^{+} \mathrm{T}$ cells accumulating in the BM not only support inflammation, but also directly affect B cell maintenance. Peripheral antibody concentrations are heavily dependent on long-living, antibody-producing, plasma cells in the BM [50]. This is clinically relevant as serum antibodies ensure protection after vaccination and in case of repeated exposure to the same pathogen [51]. We considered the possibility that the BM environment, and the accumulation of highly differentiated $\mathrm{T}$ cells may affect peripheral antibody concentrations. We investigated diphtheria-specific antibody concentrations as they are induced by one of the most commonly applied vaccines world-wide and have been demonstrated to be poorly maintained in the elderly [27].

Negative correlations were seen between diphtheriaspecific antibody concentrations and highly differentiated $\mathrm{CD} 8^{+} \mathrm{CD} 7^{+} \mathrm{T}$ cells, exhausted $\mathrm{PD}-1^{+} \mathrm{CM} \mathrm{CD} 8^{+}$ $\mathrm{T}$ cells, and PD- $1^{+} \mathrm{CM} \mathrm{CD} 4^{+} \mathrm{T}$ cells in the BM. PD-1 can be expressed on activated $T$ cells, and does not always signify an exhausted cell. PD-1 expression was found to be inversely correlated with the expression of CD45RA, with memory cells expressing the highest proportions of PD-1 [52]. We used the PD- $1^{+} \mathrm{CM}$ cell populations to represent an exhausted population because CCR7, a homing marker for lymphoid tissue which is expressed on $\mathrm{CM} \mathrm{T}$ cells, was almost undetectable in PD-1 expressing $\mathrm{CD}^{+} \mathrm{T}$ cells [24], and a high expression of PD-1 has been observed on EM $\mathrm{CD}^{+} \mathrm{T}$ cells in the PB of healthy humans [52]. Cellular senescence in the BM, indicated by expression of p21 in total BMMCs, as well as in highly-differentiated and/or senescent $\mathrm{CD}^{+} \mathrm{CD} 57^{+}$and senescent CD8 ${ }^{+}$KLRG $-1^{+}$T cells was associated with lower diphtheria-specific antibodies in the periphery. Elevated ROS levels also correlated with low antibody concentrations. The corresponding $\mathrm{T}$ cell populations in the peripheral blood barely influenced antibody concentrations. Unfortunately, no information about diphtheria vaccination was available for our samples. As our cohort includes a mixture of recently vaccinated individuals and persons vaccinated several years before, these aspects compensate each other in the correlations. Despite this, in our study it is not possible to discriminate between recently vaccinated donors with low $\mathrm{Ab}$ concentrations and donors vaccinated many years before.

In summary, these results show that cellular senescence, ROS, and the accumulation of senescent $\mathrm{CD} 8^{+} \mathrm{T}$ cells in the BM, but not in the periphery, can alter antibody production by long-lived plasma cells in the BM, leading to reduced antibody concentrations. 


\section{Conclusions}

Our work provides further evidence of the important role the BM plays in regulating the survival of memory and effector cells. Changes in the BM environment, or accumulation of certain populations may affect the survival of "healthy" memory cells and plasma cells, leading to impaired antibody production. A better understanding of these effects may help us in developing more successful approaches to maintaining life-long protective antibody titres. Strategies to fight against cellular senescence, ROS and inflammation in the BM should be addressed in future studies in order to guarantee a working adaptive immunity in the elderly.

\section{Additional files}

Additional file1: Table S1. Antibodies used in surface and intracellular staining for flow cytometry. Table S2. Comparison between correlations corrected or not corrected for age. Correlation coefficients (rp) and significances were calculated according to Pearson with correction for age, values below 0.05 were considered significant. $\mathrm{N}$ : number of samples. (DOCX $45 \mathrm{~kb}$ )

Additional file 2: Figure S1. Gating strategy for the populations of interest in the BM shown in Figures 1-3. Figure S2. Representative flow plots showing the frequency of (CD3+) T cells (a), (CD19+) B cells (b) and CD14+ monocytes (c) in a young (31 years) and an old (89 years) donors. Figure S3. Gating strategy for the populations of interest in the BM shown in Figures 5-6. Figure S4. Gating strategy for the populations of interest in the PB shown in Figures 4-5. (PPTX $255 \mathrm{~kb}$ )

\section{Abbreviations}

BM: bone marrow; BMMCs: BM mononuclear cells; NKT: natural killer T cells; PB: peripheral blood; PBMCs: PB mononuclear cells; ROS: reactive oxygen species; $T_{E M}$ : effector memory $T$ cells; $T_{E M R A}$ : effector memory cells reexpressing CD45RA

\section{Acknowledgements}

We would like to thank everyone at the Institute for Biomedical Aging research in Innsbruck, and Klinikum Wels-Grieskirchen Orthopedics who made this work possible.

\section{Authors' contributions}

Manuscript preparation: EN, LP, and BW. Experimental work: EN, LP, MK, CM and MG. Data Analysis: EN and LP. Study/Protocol design: LP, BW, and BGL. Sample collection and study design: KT. All authors read and approved the final manuscript.

\section{Funding}

This work was supported by the Austrian Science Fund (FWF; doctoral program HOROS, W1253) and by the EU H2020 project "An integrated approach to dissect determinants, risk factors, and pathways of ageing of the immune system" (ImmunoAgeing, H2020-PHC-2014 grant agreement No: 633964). The funders had no role in study design, data collection and analysis, decision to publish, or preparation of the manuscript.

\section{Availability of data and materials}

The datasets used and/or analysed during the current study are available from the corresponding author on reasonable request.

\section{Ethics approval and consent to participate}

Study approval was given by the local institution, written informed consent was received from all participants prior to their inclusion in the study in accordance with the Declaration of Helsinki.

\section{Consent for publication}

Written informed consent was received from all participants prior to their inclusion in the study/publication in accordance with the Declaration of Helsinki.

\section{Competing interests}

The authors declare that they have no competing interests.

\section{Author details}

${ }^{1}$ Institute for Biomedical Aging Research, University of Innsbruck, Rennweg 10, A-6020 Innsbruck, Austria. ²Department of Orthopedic Surgery, Hospital Wels-Grieskirchen, Grieskirchnerstrasse 42, Wels, Austria.

Received: 7 January 2019 Accepted: 14 August 2019

Published online: 22 August 2019

\section{References}

1. Boyman O, Letourneau S, Krieg C, Sprent J. Homeostatic proliferation and survival of naive and memory T cells. Eur J Immunol. 2009;39:2088-94.

2. Zhao E, Xu H, Wang L, Kyczek I, Wu K, Hu K, Wang G, Zou W. Bone marrow and the control of immunity. Cell Mol Immunol. 2012:9:11-9.

3. Chang JT, Wherry EJ, Goldrath AW. Moleular regulation of effector and memory T cell differentiation. Nat Immunol. 2014;15:1104-15.

4. Nguyen DC, Garimalla S, Xiao H, Kyu S, Albizua I, Galipeau J, Chiang K-Y, Waller EK, Wu R, Gibson G, Roberson J, Lund FE, Randall TD, Sanz I, Lee FE-H. Factors of the bone marrow microniche that support human plasma cell survival and immunoglobulin secretion. Nature communications. 2018;9:3698.

5. Herndler-Brandstetter $D$, Landgraf $K$, Tzankov A, Jenewein B, Brunauer $R$, Laschober GT, Parson W, Kloss F, Gassner R, Lepperdinger G, GrubeckLoebenstein B. The impact of aging on memory $T$ cell phenotype and function in the human bone marrow. J Leukoc Biol. 2012;91:197-205.

6. Chen L, Flies DB. Molecular mechanisms of T cell co-stimulation and coinhibition. Nat Rev Immunol. 2013;13:227-42.

7. Pangrazzi L, Naismith E, Meryk A, Keller M, Jenewein B, Trieb K, GrubeckLoebenstein B. Increased IL-15 production and accumulation of highly differentiated CD8+ effector/memory $T$ cells in the bone marrow of persons with Cytomegalovirus. Frontiers. 2017:8:1-9.

8. Mou D, Espinosa J, Lo DJ, Kirk AD. CD28 negative T cells: is their loss our gain? Am J Transplant. 2014;14:2460-6.

9. Herndler-Brandstetter $D$, Landgraf $K$, Jenewein $B$, Tzankov A, Brunauer $R$, Brunner S, Parson W, Kloss F, Gassner R, Lepperdinger G, GrubeckLoebenstein B. Human bone marrow hosts polyfunctional memory CD4+ and CD8+ T cells with close contact to IL-15-producing cells. J Immunol. 2011;186:6965-71.

10. Strioga M, Pasukoniene V, Characiejus D. CD8+CD28- and CD8+CD57+ T cells and their role in health and disease. Immunol. 2011;134:17-32.

11. Pangrazzi L, Meryk A, Naismith E, Koziel R, Lair J, Krismer M, Trieb K, Grubeck-Loebenstein B. "Inflamm-aging" influences immune cell survival factors in human bone marrow. Eur J Immunol. 2017:47:481-92.

12. Pritz T, Lair J, Ban M, Keller M, Weinberger B, Krismer M, GrubeckLoebenstein B. Plasma cell numbers decrease in bone marrow of old patients. Eur J Immunol. 2015:45:738-46.

13. Tokoyoda K, Zehentmeier S, Hegazy A, Albrecht I, Gruen J, Loehning M, Radbruch A. Professional memory CD4+ T lymphocytes preferentially reside and rest in the bone marrow. Immunity. 2009;30:721-30.

14. Lopez-Otin C, Blasco MA, Partridge L, Serrano M, Kroemer G. The hallmarks of aging. Cell. 2013;153:1194-217.

15. Coppé J-P, Desprez P-Y, Krtolica A, Campisi J. The senescence-associated secretory phenotype: the dark side of tumor suppression. Annu Rev Pathol. 2010;5:99-118.

16. Daste A, Domblides C, Gross-goupil M, Chakiba C, Quivy A, Cochin V, de Mones E, Larmonier N, Soubeyran P, Ravaud A. Immune checkpoint inhibitors and elderly people: a review. Eur J Cancer. 2017;82:155-66.

17. Althubiti M, Lezina L, Carrera S, Jukes-Jones R, Giblett SM, Antonov A, Barlev N, Saldanha GS, Pritchard CA, Cain K, Macip S. Characterization of novel markers of senescence and their prognostic potential in cancer. Cell Death \&Amp; Disease. 2014:5:e1528

18. Fischer M. Census and evaluation of p53 target genes. Oncogene. 2017;36:3943.

19. Yosef R, Pilpel N, Papismadov N, Gal H, Ovadya Y, Vadai E, Miller S, Porat Z, Ben-Dor S, Krizhanovsky V. p21 maintains senescent cell viability under 
persistent DNA damage response by restraining JNK and caspase signaling. EMBO J. 2017;36:2280-95.

20. Ouyang $Q$, Wagner WM, Voehringer D, Wikby A, Klatt T, Walter S, Müller CA, Pircher H, Pawelec G. Age-associated accumulation of CMV-specific CD8+ T cells expressing the inhibitory killer cell lectin-like receptor G1 (KLRG1). Exp Gerontol. 2003;38:911-20.

21. Taylor S, Huang Y, Mallett G, Stathopoulou C, Felizardo TC, Sun M-A, Martin EL, Zhu N, Woodward EL, Elias MS, Scott J, Reynolds NJ, Paul WE, Fowler DH, Amarnath S. 2017. PD-1 regulates KLRG1\&lt;sup\&gt;+\&lt;/sup\&gt; group 2 innate lymphoid cells. The Journal of Experimental Medicine.

22. Catakovic K, Klieser E, Neureiter D, Geisberger R. T cell exhaustion: from pathophysiological basics to tumor immunotherapy. Cell Communication and Signaling: CCS. 2017;15:1.

23. Simon S, Labarriere N. PD-1 expression on tumor-specific T cells: friend or foe for immunotherapy? Oncoimmunology. 2018;7:e1364828.

24. Hong JJ, Amancha PK, Rogers K, Ansari AA, Villinger F. Re-evaluation of PD-1 expression by T cells as a marker for immune exhaustion during SIV infection. PLoS One. 2013;8:e60186.

25. Wherry EJ, Kurachi M. Molecular and cellular insights into T cell exhaustion. Nat Rev Immunol. 2015;15:486-99.

26. Wang H, Gonzalez-Garcia I, Traba J, Jain S, Conteh S, Shin D-M, Qi C, Gao Y, Sun J, Kang S, Abbasi S, Naghashfar Z, Yoon J, DuBois W, Kovalchuk AL, Sack MN, Duffy P, Morse HC. ATP-degrading ENPP1 is required for survival (or persistence) of long-lived plasma cells. Sci Rep. 2017;7:17867.

27. Grasse M, Meryk A, Schirmer M, Grubeck-Loebenstein B, Weinberger B. Booster vaccination against tetanus and diphtheria: insufficient protection against diphtheria in young and elderly adults. Immunity \& Ageing : I \& A. 2016;13:26

28. World Health Organization. Diphtheria vaccine - WHO position paper. Wkly Epidemiol Rec. 2006;81:24-31.

29. Tu W, Rao S. Mechanisms underlying T cell immunosenesence: aging and Cytomegalovirus infection. Front Microbiol. 2016;7:1-12.

30. Pawelec G, Akbar A, Beverley P, Caruso C, Derhovanessian E, Fülöp T, Griffiths P, Grubeck-Loebenstein B, Hamprecht K, Jahn G, Kern F, Koch SD, Larbi A, Maier AB, Macallan D, Moss P, Samson S, Strindhall J, Trannoy E, Wills M. 2010. Immunosenescence and Cytomegalovirus: where do we stand after a decade? Immunity \& Ageing : I \& A 7: 13-

31. Pawelec $\mathrm{G}$, Derhovanessian E. Role of CMV in immune senescence. Virus Res. 2011;157:175-9.

32. Moser K, Tokoyoda K, Radbruch A, MacLennan I, Manz RA. Stromal niches, plasma cell differentiation and survival. Curr Opin Immunol. 2006;18:265-70.

33. Brynjolfsson SF, Mohaddes M, Kärrholm J, Wick M-J. Long-lived plasma cells in human bone marrow can be either CD19(+) or CD19(-). Blood Advances. 2017:1:835-8.

34. Romanyukha A, Yashin A. Age related changes in population of peripheral $T$ cells: towards a model of immunosenescence. Mech Ageing Dev. 2003;124:433-43.

35. Bradley LM, Haynes L, Swain SL. IL-7: maintaining T-cell memory and achieving homeostasis. Trends Immunol. 2005;26:172-6.

36. Corfe SA, Paige CJ. The many roles of IL-7 in B cell development; mediator of survival, proliferation and differentiation. Semin Immunol. 2012;24:198-208.

37. Sammicheli S, Ruffin N, Lantto R, Vivar N, Chiodi F, Rethi B. IL-7 modulates B cells survival and activation by inducing BAFF and CD70 expression in T cells. J Autoimmun. 2012;38:304-14.

38. Li R, Paul A, Ko KWS, Sheldon M, Rich BE, Terashima T, Dieker C, Cormier S, Li L, Nour EA, Chan L, Oka K. Interleukin-7 induces recruitment of monocytes/macrophages to endothelium. Eur Heart J. 2012;33:3114-23.

39. N-p W, Akbar AN, Goronzy J. CD28(-) T cells: their role in the age-associated decline of immune function. Trends Immunol. 2009;30:306-12.

40. Kared H, Martelli S, Ng TP, Pender SL, Larbi A. CD57 in human natural killer cells and T-lymphocytes. Cancer Immunol Immunother. 2016;65:441-52.

41. Fry TJ, Mackall CL. The many faces of IL-7: from Lymphopoiesis to peripheral T cell maintenance. J Immunol. 2005;174:6571-6.

42. Tohyama T, Takano T, Yamamura H. B cell responses to oxidative stress. Curr Pharm Des. 2004;10.

43. Frasca D, Diaz A, Romero M, Landin AM, Blomberg BB. Age effects on $B$ cells and humoral immunity in humans. Ageing Reseach Reveiws. 2011; 10:330-5.

44. De Martinis M, Modesti M, Loreto MF, Quaglino D, Ginaldi L. Adhesion molecules on peripheral blood lymphocyte subpopulations in the elderly. Life Science. 2000;68:139-51.

45. de Bruin AM, Voermans C, Nolte MA. Impact of interferon- $\gamma$ on hematopoiesis. Blood. 2014;124:2479-86.
46. Stavnezer J, Amemiya CT. Evolution of isotype switching. Semin Immunol. 2004;16:257-75

47. Brandsma C, Hylkema M, Geerlings M, vanGeffen W, Postma D, Timens W, Kerstjens $\mathrm{H}$. Increased levels of (class switched) memory B cells in peripheral blood of current smokers. Respir Res. 2009;10:108.

48. Larbi AR, Vasudev A, Low I, Binte Shadan N, Mustafa S, Ayyadhury S, Fulop T. The immune system in the elderly: a fair fight against diseases? Aging Health. 2013;9:35-47.

49. Gao Y, Grassi F, Ryan MR, Terauchi M, Page K, Yang X, Weitzmann MN, Pacifici R. IFN- $\gamma$ stimulates osteoclast formation and bone loss in vivo via antigen-driven T cell activation. J Clin Invest. 2007;117:122-32.

50. Slifka MK, Matloubian M, Ahmed R. Bone marrow is a major site of long-term antibody production after acute viral infection. J Virol. 1995; 69:1895-902.

51. Zinkernagel RM, Hengartner $\mathrm{H}$. Protective 'immunity' by pre-existent neutralizing antibody titers and preactivated T cells but not by so-called 'immunological memory'. Immunol Rev. 2006;211:310-9.

52. Duraiswamy J, Ibegbu CC, Masopust D, Miller JD, Araki K, Doho GH, Tata P, Gupta S, Zilliox MJ, Nakaya HI, Pulendran B, Haining WN, Freeman GJ, Ahmed R. Phenotype, function, and gene expression profiles of programmed Death-1<sup >hi</sup> CD8 T cells in healthy human adults. J Immunol. 2011;186:4200-12.

\section{Publisher's Note}

Springer Nature remains neutral with regard to jurisdictional claims in published maps and institutional affiliations.
Ready to submit your research? Choose BMC and benefit from:

- fast, convenient online submission

- thorough peer review by experienced researchers in your field

- rapid publication on acceptance

- support for research data, including large and complex data types

- gold Open Access which fosters wider collaboration and increased citations

- maximum visibility for your research: over $100 \mathrm{M}$ website views per year

At BMC, research is always in progress.

Learn more biomedcentral.com/submissions 